Volume 8, No.6, November - December 2019

International Journal of Advanced Trends in Computer Science and Engineering

Available Online at http://www.warse.org/IJATCSE/static/pdf/file/ijatcse49862019.pdf

https://doi.org/10.30534/ijatcse/2019/49862019

\title{
Design of Loyalty Systems based on Service Oriented Architecture at XYZ Company
}

\author{
Andika Syafiq Baskara ${ }^{1}$, Sfenrianto $^{2}$ \\ ${ }^{12}$ Information Systems Management Department, BINUS Graduate Program - Master of Information Systems \\ Management, Bina Nusantara University, Jakarta 11480 \\ 1'andika.baskara@binus.ac.id, ${ }^{2}$ sfenrianto@binus.edu
}

\begin{abstract}
Every Company must adapt and maintaining existence by using Service Oriented Architecture (SOA). It is emphasizing flexibility and reusability add value to the company system. $\mathrm{XYZ}$ Company is an engaged in the air transportation business. To face competition the Company should be has a loyalty system that aims to increase engagement with customers, help to maintain existing customers, and as an attraction for prospective customers. The purpose of study is to design a loyalty system based on Service Oriented Architecture (SOA). The results of this study are a Service Oriented Architecture (SOA) based loyalty system design, the system design includes application architecture, application infrastructure, network infrastructure, and process business design. .
\end{abstract}

Key words : system design, service oriented, architecture, loyalty

\section{INTRODUCTION}

Business competition in various fields currently is inevitable, the airline sector is no exception. And to compete with other airlines, it requires innovation and maximum attractiveness to retain customers, one of the innovations that can be done is to create a loyalty system for customers.

The main purpose of the loyalty system is to establish good relations with customers, increase customer satisfaction, and make customers become loyal customers to the Company by using technology. The loyalty system in the field of aviation (commonly called Frequent Flyer) by targeting Customer loyalty [1]. It is need for business and relation customer. Maintaining customers by providing various services with various advantages having a loyal customer base, helping company increased increase profit [2].
The XYZ Company as one of the airlines should be implement a loyalty system to increase engagement with its customers. The main business processes of loyalty given to customers of these Company include Enrollment, Accrual, Redemption, Retro Claim and Member Promotion. The loyalty business process requires partners as supporters. With such conditions, XYZ Company must maintain good relations with partners to support the business process of loyalty to customers. Based on internal data provided by XYZ Company, the average demand per month for major business processes (see Table 1).

Table 1: Number of Request for each Business

\begin{tabular}{|l|c|l|c|}
\hline \multirow{2}{*}{ No } & Business & \multicolumn{1}{|c|}{ Source } & $\begin{array}{c}\text { Number of } \\
\text { Request }\end{array}$ \\
\hline 1. & \multirow{2}{*}{ Enrollment } & Partner (File) & 800 \\
\cline { 3 - 4 } & & $\begin{array}{l}\text { Internal (by } \\
\text { System) }\end{array}$ & 200 \\
\hline 2. & Accrual & Partner (File) & 24000 \\
\cline { 3 - 4 } & & $\begin{array}{l}\text { Internal (by } \\
\text { System) }\end{array}$ & 18000 \\
\hline 3. & Redemption & $\begin{array}{l}\text { Internal (by } \\
\text { System) }\end{array}$ & 15000 \\
\hline 4. & Retro Claim & Partner (File) & 12000 \\
\cline { 3 - 4 } & & $\begin{array}{l}\text { Internal (by } \\
\text { System) }\end{array}$ & 1000 \\
\hline
\end{tabular}

The Company has several obstacles and problems that are obtained from customers and partners. The slow activity of the customer to enter the system running. The second problem that is most often complained about the results of exchanging points in the form of vouchers that cannot be used because the voucher data has not been received by partners. Both problems greatly affect customer satisfaction. When viewed from loyalty system that need the Company is the exchange of data and information that is carried out between the loyalty system and the partners involved. Exchange of data and information is currently still done through files sent from partners to the manual system and vice versa.

The SOA approach can be a good solution for XYZ Company. It is an abstraction of a functionality or business process. System design that wants to be realized is a system that has 
various micro services that are grouped according to the business process that run on the loyalty system of XYZ Company and can be accessed by both partners and outside parties in need. In addition, by utilizing SOA, XYZ Company is able to add value to the loyalty system, such as effectivity, flexibility, and reusability.

\section{LITERATURE REVIEW}

\subsection{Loyalty Systems}

Company loyalty is needed to maintain good relations with customers because emotional customers in shopping are influenced by the underlying psychological circumstances. The situation will reflect the level of the company's relationship with individual customers, which leads to a favorable attitude. Loyal customers will continue to buy from the company because they psychologically have a deep emotional element. This type of loyalty is similar to blind loyalty because it has an emotional element [3].

Due to the different nature between company and customer loyalty. Customer loyalty is more emotionally driven. While company loyalty is driven more by business profits. Thus, the quality of the relationship the customer has with the Company can be programmed with a loyalty program that can benefit the company. Loyalty programs are needed to provide additional value that benefits a company's business.

Previous research has argued that "attractive company services, maybe customers will be loyal to the company" [4]. Customer loyalty has tangible benefits that can increase the likelihood of repurchases. Strategy building good customer loyalty affects competitive advantage. Lack of customer loyalty to certain companies raises the inability to win the competition [5].

In addition, competitive advantage is a unique position that is important for companies to develop in the face of competitors and maybe the company can outperform them consistently. Efforts to improve competitive advantage, one of the keys to success is determined by the existence loyal customers [5]. Therefore, we need a strategy in building customer loyalty in increasing competitive advantage. [5].

Business with loyal customers will be better, if compared to the market has decreased attractiveness. Actually, consumers will tend to be easily loyal if they feel valued [6]. Companies can use a variety of strategies to lure consumers, such as whether the company remembers the date of the consumer's birthday, or the last item they bought? Many businesspeople use e-mail programs that will send special e-mails with birthday wishes to consumers and discounts during the consumer's birth month. This will make consumers feel valued.
Consumer loyalty is a measure of the number of times consumers make a purchase or participate in a business. Every company can have various ways to measure customer loyalty. But the most basic way that can be done is to look at the number of purchases made by consumers in a database. Consumers who make purchases repeatedly are the most valuable consumers. There are many benefits that can be obtained by having loyal customers. Besides being able to increase profits, producers will also often get good reviews from consumers. This is very important to gain potential consumer confidence. That is why until now many businesspeople are doing various ways to increase consumer loyalty.

\subsection{SOA - Microservice}

Micro services are integrated interaction processes through messages. For example, consider services whose complexity must provide good planning. From a technical point of view, Microserservice must be a component that is conceptualized independently and equipped with a database. Because all components of the micro service architecture are service component coordination through messages [7].

The microservices architecture is a distributed application where all the modules are microdevices. Microservices architecture principles help Managers and project developers: This provides guidance for the design and implementation of distributed applications. Following this principle, developers focus on implementing and testing multiple cohesive functions. This applies also to high-level Microsoft services, which relate to coordinating the functions of other microservices services [7]. This approach has been built based on SOA concepts brought from cross border workflows to application level and into application architecture, e.g. Service-oriented architecture and its programming from large to small. The term "microservices" was first introduced in 2011 in an architecture workshop as a way to illustrate the general ideas of participants in the pattern of software architecture. Until then, this approach is also known by different names. For example, Netflix uses a very similar architecture to the name of Fine Grained SOA [8] [9].

By making the service completely independent in development and deployment, the Microsoft service emphasizes on loose couplings and high cohesion by bringing modularity to the next level. This approach provides all sorts of benefits in terms of treatment, scalability and so on. It also comes with a number of problems inherited from the distributed system and from the SOA, its predecessor [7].

The architecture of Microservices still shows the distinctive characteristic that blends into something unique and distinct 
from the SOA itself: The main system characteristics for microservices are [7], namely: (1) Flexibility - a system capable of following the ever-changing business environment and able to support all necessary modifications to keep the organization competitive in the market; (2) Modularity - a system consists of an isolated component in which each component contributes to the overall system behavior rather than having a single component that offers full functionality; and (3) Evolution - a system has to be maintained while continuously evolving and adding new features.

\section{DESIGN OF LOYALTY SYSTEM}

\subsection{Application Architecture}

The SOA-based loyalty system must be supported with the appropriate application architecture so that it can be run properly without a functional and performance major issue. Application architecture is recommended for the SOA-based loyalty system for XYZ Company. In the recommended application architecture, there are several add-ons to improve effectiveness, facilitate monitoring, and report generator. With SOA as base, the type of communication between core system and support system is done through API or Batch. To get a more detailed understanding of the application Architecture system loyalty XYZ Company can be seen in the following image.

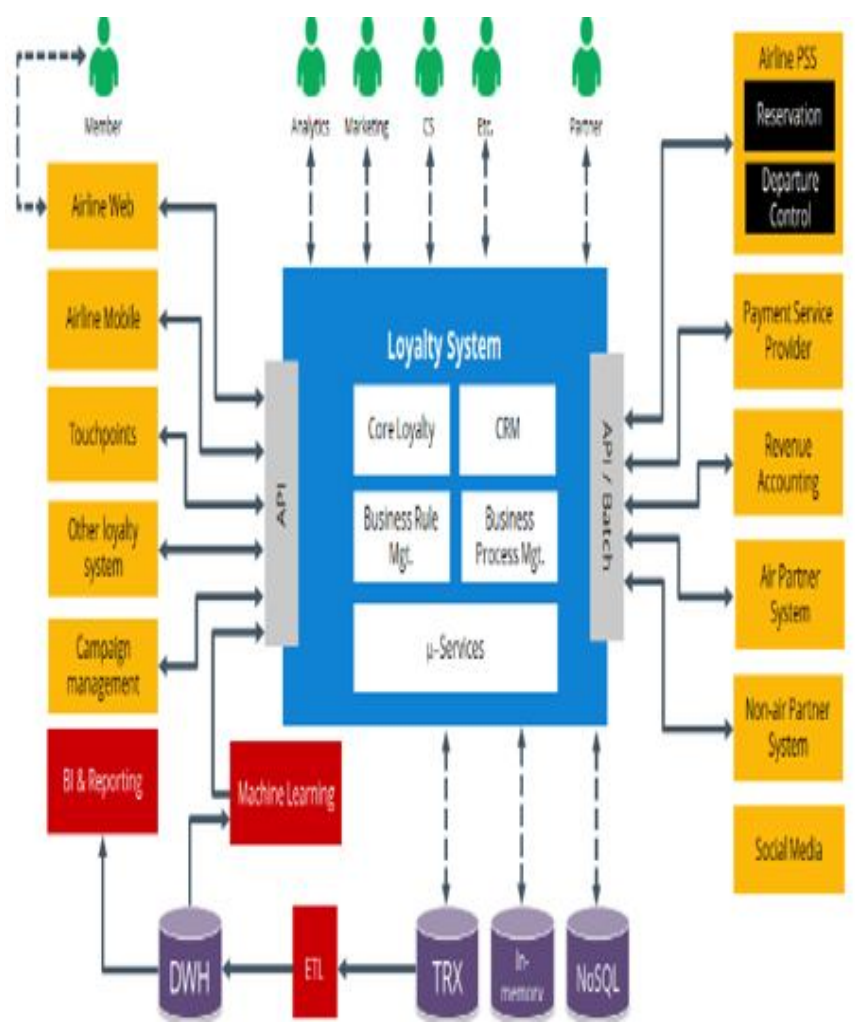

Figure 1: Recommended Application Architecture System Loyalty XYZ Company
Based on Figure 1 there are 3 main parts of the loyalty system, the first part is the core system where the core business process of the loyalty is executed, the core system will expose the API to be accessed by the surrounding application or batch will then be executed to process the files provided by the surrounding application.

The second part is the surrounding application that will access the API as communication advice with the core system. And the last part is data management from loyalty system, there are database, Data Warehouse, and machine learning as one of data processing tools from loyalty system.

\subsection{Application Infrastructure}

Application infrastructure from applications determined from the requirement specified from the application. Some requirement includes performance rate, functionality, cost, maintenance, and timeframe from application development. Based on the data obtained from the observation, interviews, and studying the technical documents, the following is a recommendation for application infrastructure Draft for the loyalty system of XYZ Company.

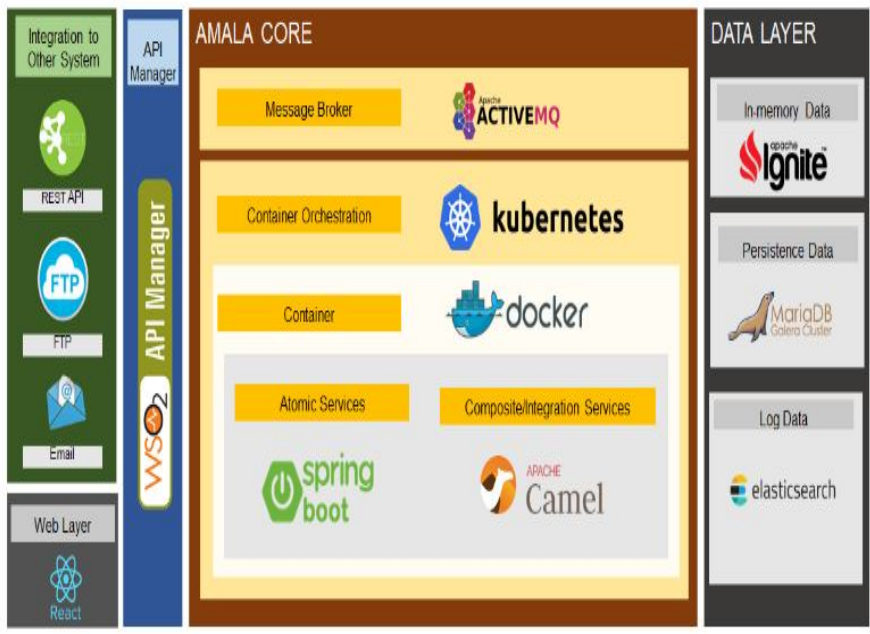

Figure 2: Recommendation of Application Infrastructure of Loyalty system XYZ Company

Based on figure 2, there are 4 (four) layers of the application infrastructure system loyalty, namely: Integration Layer, API Manager, Core System, and Data Layer: Integration Layer, the integration layer is the part where the surrounding application performs communication with the core system. There are several methods of communication that can be done on the integration layer, namely REST API, FTP Server, Email, and Web Layer.

API Manager, all communication done on the integration layer will be handle by API Manager. The loyalty system to be created will be stale SOA, it is necessary a layer to arrange the 
communication received by the system. The types of governance that API Manager does include routing, and security management from API access.

Core System consists of several layers in it, which each layer has different roles and supports each other's SOA-based system. The layers on the core system, namely: (1) Message Broker is responsible for the management of asynchronous communication; (2) Container serves as the packaging of each services in the loyalty system; (3) MicroServices is a service that dependency or use another service to run; and (4) . Composite/Integration Layer for complex business processes and the processing of a lot of data, there needs to be a service that performs orchestration and integration.

Data Layer, the data management activity is done on this layer, there are 3 places of data management in the loyalty system that has been designed.The data management activity is done on this layer.

\subsection{Network Infrastructure}

Network Infrastructure created to facilitate the SOA-based loyalty system requires good planning, in order to produce a stable system and have a fast and good performance. For the SOA-based loyalty system for XYZ Company (see figure 3).

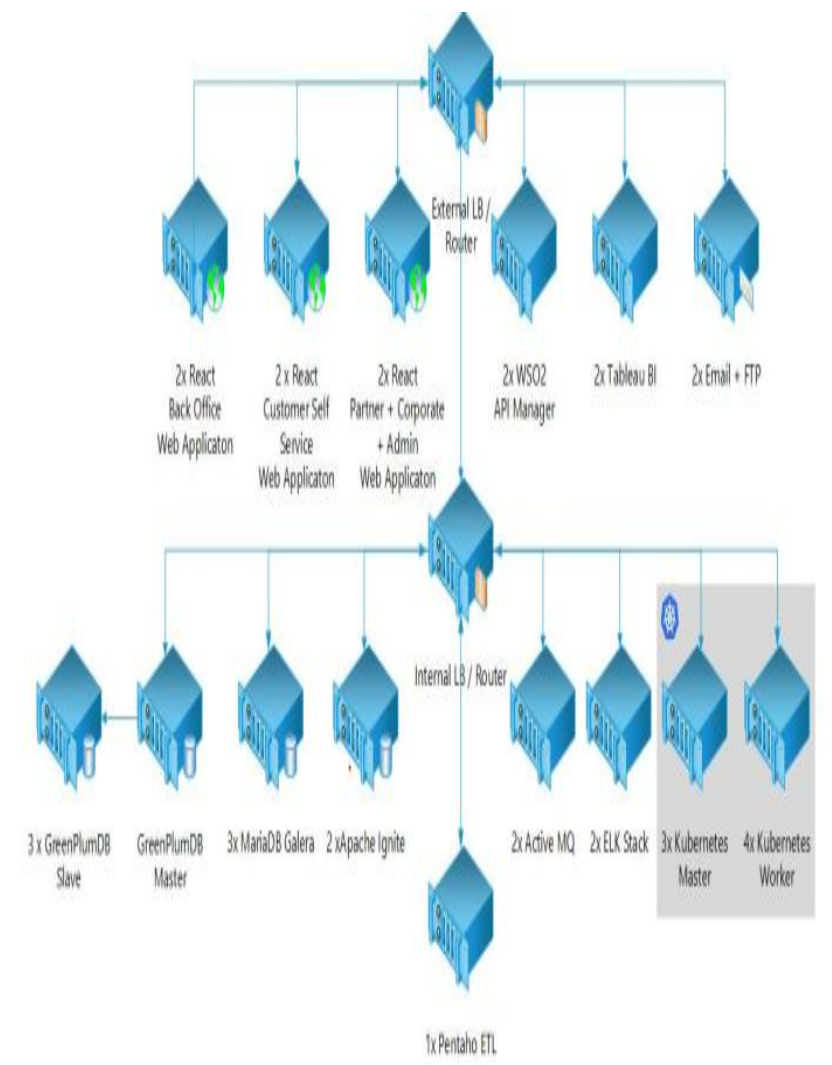

Figure 3: Network Infrastructure of Loyalty system XYZ Company recommendation
In the network infrastructure design image (Figure 3), the part that has an important role is the load balancer. The design of the researcher creates 2 load balancers, each of which will handle requests from external and internal. External load balancers are used to handle all requests obtained on the integration layer. An external load Balancer will forward requests to the internal load balancer. The Internal load balancer will set the load according to the request requirement.

The Load balancer regulates the sharing of incoming requests so that the request does not overlap and is flat, it will impact directly on the performance of the loyalty system. According to the data received the business request entered into the loyalty traffic system is very high, so it needs to be supported with maximum network infrastructure.

\section{.4. DESIGN OF LOYALTY SYSTEM BASE SOA}

\subsection{Business Process Design}

Each business at XYZ Company has its own complexity. Here is an overview of the business process respectively. Enrollment is a customer registration process to become a member. If you are a member, then the customer is entitled to earn miles for each activity accrual performed by the member. These Miles can then be used to perform the redemption process (see Figure 4).

Based on Figure 4, the enrollment process start from viewed from the source data, divided into 2 channels, the first channel is where members register directly through the provided place (website, mobile apps), and the second is through the file. In general, the enrollment process through files is done by a parter working with XYZ Company. If the enrollment process has been successfully completed, then the member will have a member attribute that will be used for the accrual process, redemption, even the process of obtaining the promo. 


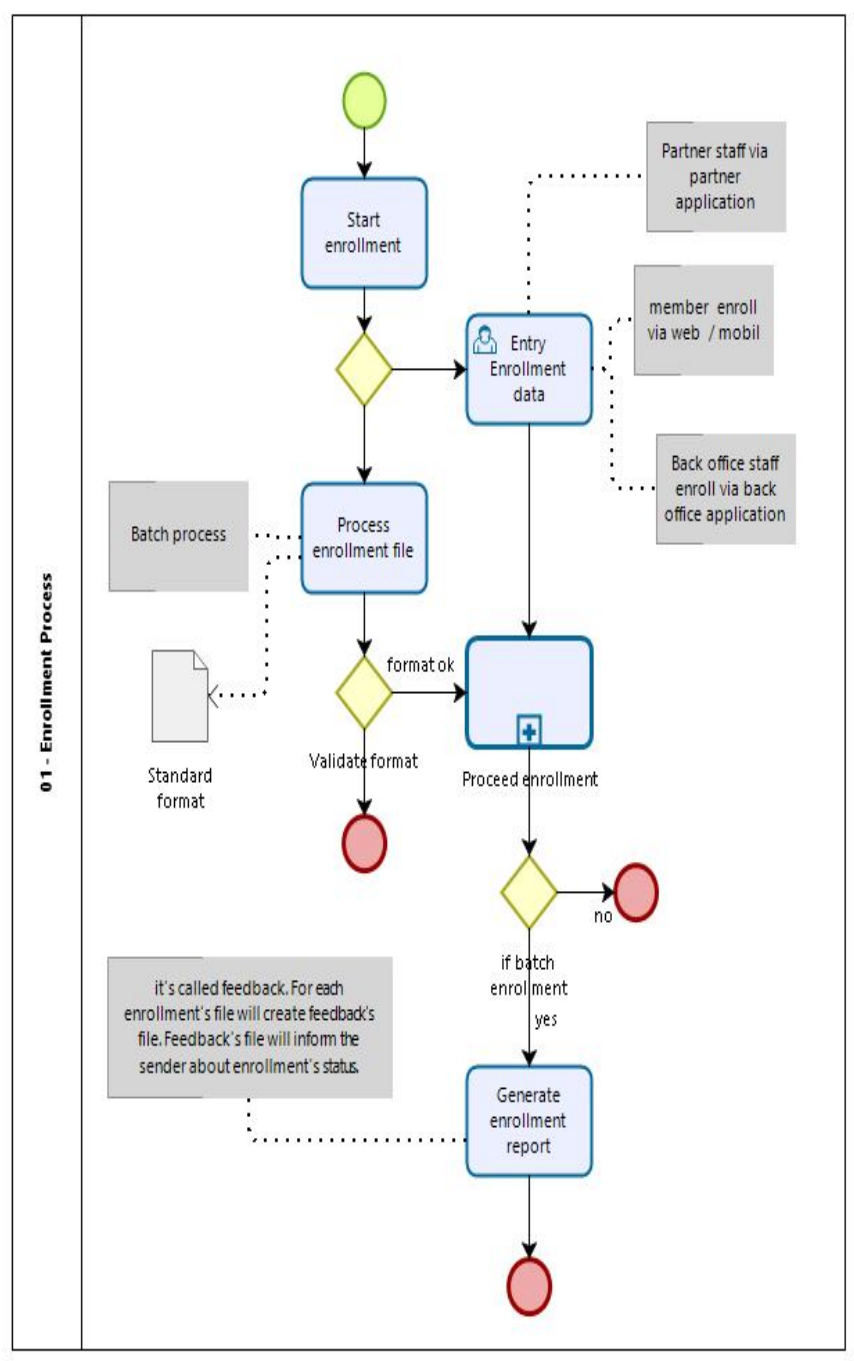

Figure 4: Enrollment BPMN

Then, accrual is the process of converting activities carried out by members into miles that can be used by members for redemption. Accrual is done through the application or through files. Accrual process There are 2 types, accrual for water activity and accrual for non-air activity. Each activity has a rule to convert. Air activity is a member activity that comes from the flight. The activity will see the flight data and match the member ID of the flight data with the member ID of the loyalty system. If the member ID, the next found data will be validated and deposes for its value conversion. If successfully converted, then the miles of the conversion result will be added to the member's account.

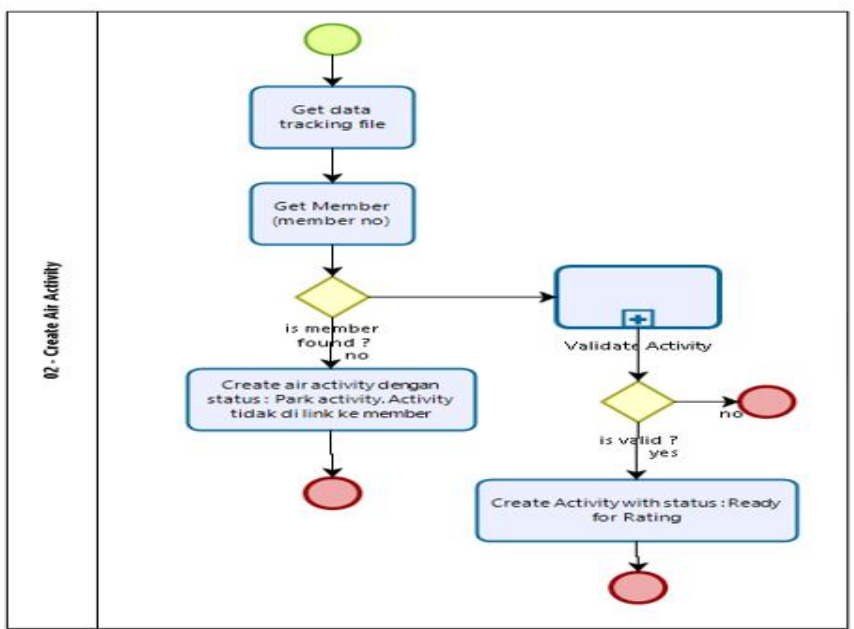

Figure 5: Air Activity Process

Non air activity is the activity of members who come from transaction activities on the loyalty system partners, for example members stay in hotels that cooperate with the loyalty system. The hotel partners will send data to the loyalty system to be validated and converted into miles (see figure 6).

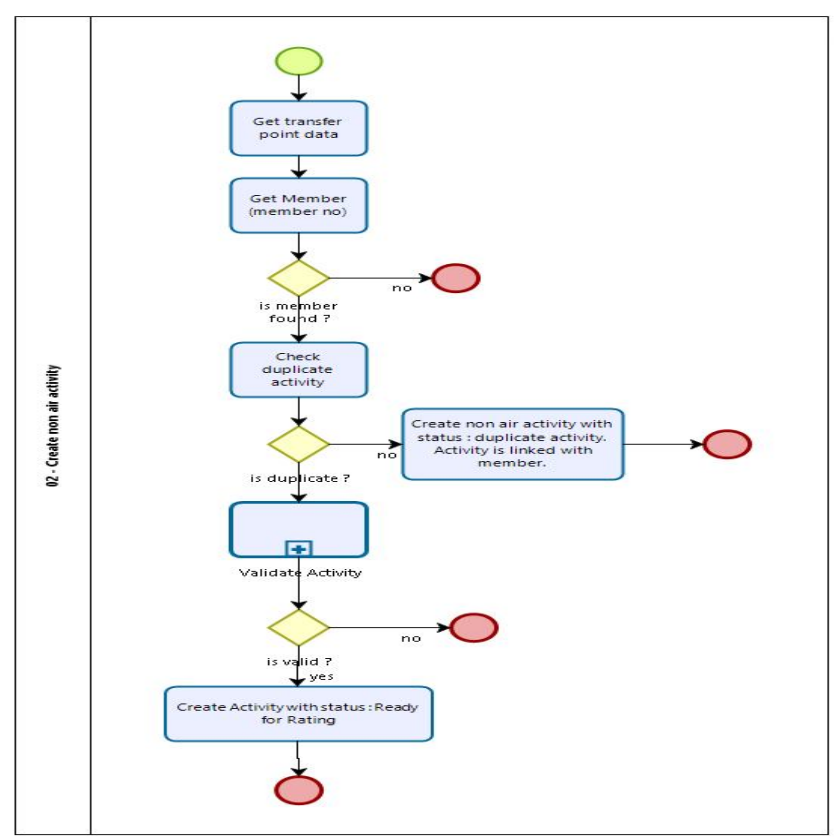

Figure 6: Non-Air Activity Process

Then, redemption is the process of redemption of miles belonging to the member into vouchers or tickets. redemption process explained. First, voucher or ticket obtained by member, will be used to make transactions in the partner/merchant. Next, the partner/merchant will validate the voucher or ticket and will charge the XYZ Company at the time of the specified period. For redemption staff loyalty must first do the data setup in the system and provide information to the partner. After that the staff will create a rule of redemption. Rule redemption includes, the number of miles to be deducted from the member, the maximum number of redemption that can be made by the member, to the validity 
period of the voucher or ticket. At the end of the period, the partner will send a reporting on the amount of redemption that has been done and the data of the redemption member.

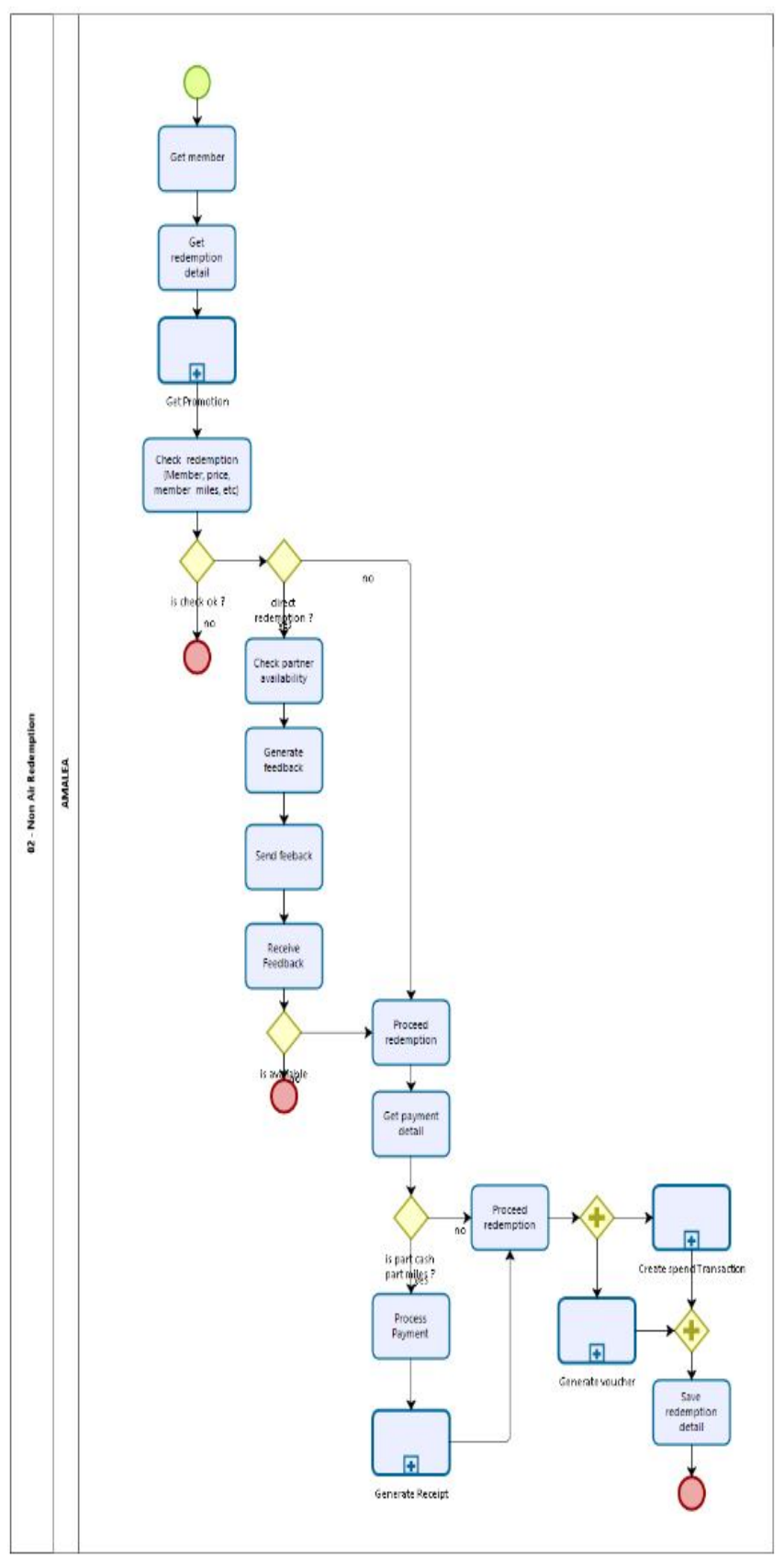

Figure 7: Redemption Process

Promo is a means of XYZ Company, to get new members, or improve the activities done by members. The Promo is planned and involves a partner/merchant in the process. Promo has several types, ranging from accrual promo, redemption promo, to enrollment promo. Promo can be setup according to the condition and needs of loyalty system. Generally, promo in setup based on membership level owned by member. In addition to the setup catalog of the promo, team loyalty will setup promo rules. This is done to prevent a promo overload or a promo that does not match the target (see figure 8).

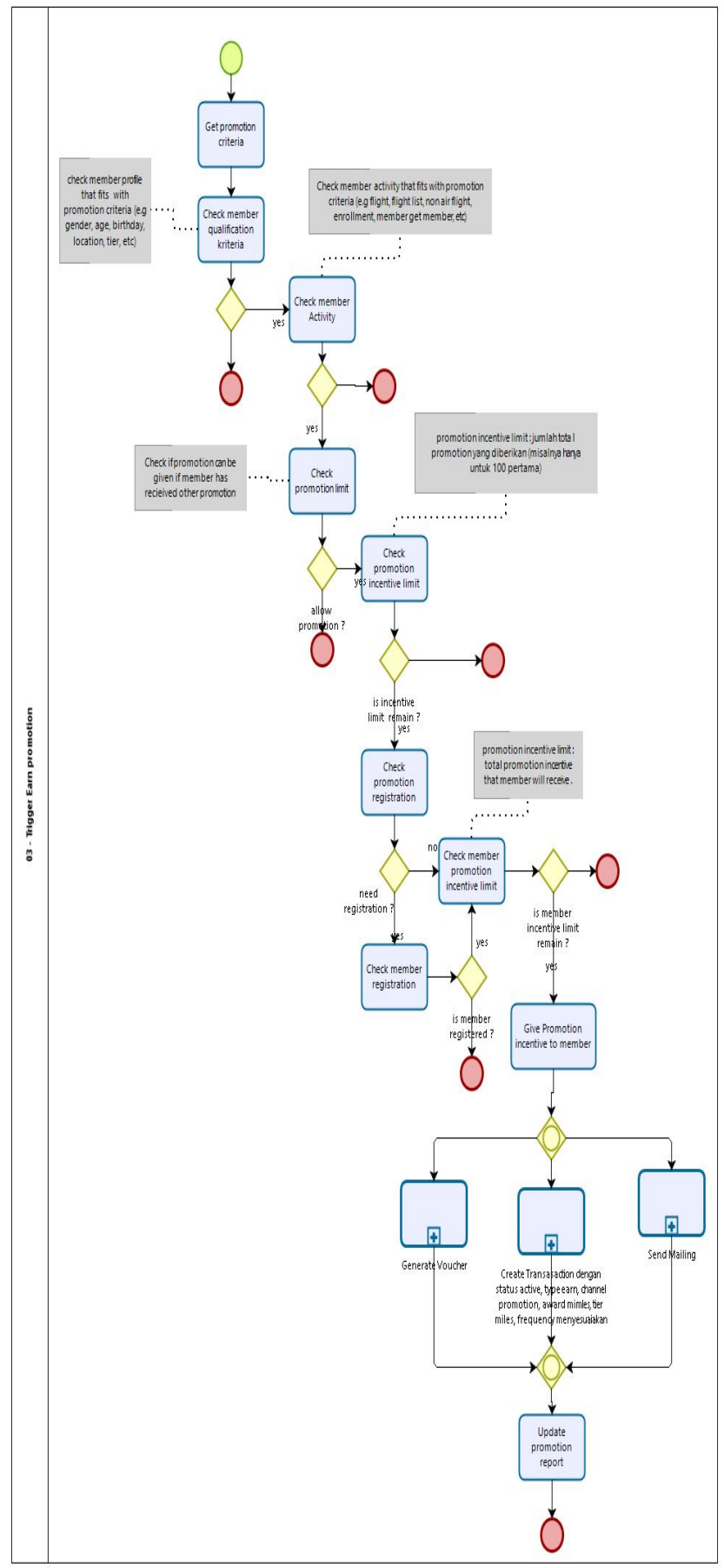

Figure 8: Promo Process

\section{CONCLUSION}

Based on design that has been done through the study, it can be concluded that the results of loyalty system design, includes application architecture, application infrastructure, and network infrastructure, The Design should be able to help maximize the running business process in a Company and add value from the company. Then, in conducting a design of loyalty system based on Service Oriented Architecture (SOA) is proposed process business design the system. 


\section{REFERENCES}

1. E. \&. G. S. de Boer, "30 years of frequent flyer programs," Journal of Air Transport Management, pp. 18-24, 2012.

https://doi.org/10.1016/j.jairtraman.2012.05.003

2. P. Varma, "What is the importance of loyalty program and why do you need it ?," Quora, 3 February 2017.: https://www.quora.com/What-is-the-importance-of-loya lty-program-and-why-do-you-need-it. [Accessed 27 September 2018].

3. A. S. \&. B. K. Dick, "Customer loyalty: toward an integrated conceptual framework," Journal of the Academy of Marketing Science, vol. 22, pp. 99-113, 1994.

https://doi.org/10.1177/0092070394222001

4. [4] Wahyuaji, B., \& Ramli, K. (2019). Cnds-syn flood prevention using distributed firewall in software-defined wan architecture. International, Journal of Advanced Trends in Computer Science and Engineering, 8(1.4 S1), 182-186.

https://doi.org/10.30534/ijatcse/2019/2881.42019

5. Evanschitzky, H., Ramaseshan, B., Woisetschläger, D. M., Richelsen, V., Blut, M., \& Backhaus, C. (2012). Consequences of customer loyalty to the loyalty program and to the company, Journal of the Academy of Marketing Science, 40(5), 625-638. https://doi.org/10.1007/s11747-011-0272-3

6. P. \&. L. H. Luarn, "A customer loyalty model for e-service context," Commerce Res, vol. 4, pp. 156-167, 2003.

7. Dragoni, N., Giallorenzo, S., Lafuente, A. L., Mazzara, M., Montesi, F., Mustafin, R., \& Safina, L. (2017). Microservices: yesterday, today, and tomorrow, In Present and ulterior software engineering (pp. 195-216). Springer, Cham. https://doi.org/10.1007/978-3-319-67425-4_12

8. MacKenzie, C. M., Laskey, K., McCabe, F., Brown, P. F., Metz, R., \& Hamilton, B. A. (2006). Reference model for service-oriented architecture 1.0. OASIS standard, 12(S 18).

9. Ganesha, D., \& Venkatamuni, V. M. (2018). Implementation of modified $Q$ learning technique in EMCAP control architecture. International Journal of Engineering \& Technology, 7(1.5), 269-273.

https://doi.org/10.14419/ijet.v7i1.5.9160 